\section{Science in fiction}

SIR - The late John Treherne's dismissive review (Nature 342, 304-305; 1989) almost put me off reading Carl Djerassi's new novel Cantor's Dilemma - "what were Djerassi's motives in writing in such a stomach-turning way about such a ghastly bunch of repellent characters?", he asks.

I discovered that the novel addresses, in a very effective and powerful way, important contemporary questions about the motivation of scientists. I am certain that it will do great service to the scientific community. Non-scientists, who are often baffled by the conflicts, rivalries, paranoia, human insensitivity, apparent social irresponsibility and even fraud that they think they sometimes perceive in us, will find illumination in this compassionate but unflinching treatment of the way scientists live. It is satisfying in itself as a novel and is a first rate read - even Treherne says "Carl Djerassi can write there is no doubt about that".

Part of the skill of the novel is that it starts with a bunch of scientists who are indeed portrayed as others see us complete with narrow views of life and self-seeking amibitions. But then the human and moral dimensions emerge and (for some) the better sides, as characters are put under pressure from the consequences of the pursuit of research. Who exploits whom in a professor-postdoc relationship? Why do such symbioses (if that is what they are) develop in scientific research when they do not seem to in the humanities? How can a superior know whether fabrication of results is going on in his team? How does an honest woman researcher come to terms with sexism on the one hand and positive discrimination on the other?

These and many other contemporary questions are vividly illustrated with all the gut-wrenching fears and tensions that go with them. Some of the issues foreshadow and indeed might in part have been inspired by the controversy about Stehelin which erupted with the award of the Nobel prize to Varmus and Bishop last year; although the book must have been finished before that time, the problem had been smouldering for years and Djerassi, like Varmus and Bishop, lives in California.

Djerassi brings into the 1990 s themes that were first explored in an earlier scientific world by C. P. Snow and William Cooper, but he adds new ones that have become more prominent in our more careerist times. There are villains as well as good guys in the story - though not by any means as many as Treherne suggests. The disappointed and selfseeking Krauss can to some extent be compared with Snow's Nightingale or Cooper's Dibdin, but he has an armoury of manipulative skills for persisting towards his ends that are whole worlds of sophistication greater. Djerassi's skilful deployment of his characters plays on the latent paranoia that a scientist can experience when he fears having made a careerbreaking and public mistake, and sets up the central conflict between Cantor and Stafford, trapping them in a struggle with themselves and each other. It is around this tension that Djerassi weaves the contemporary issues and constructs the highly original plot.

I do hope that your negative review will not prevent this book from being as widely read as it deserves.

\section{Medical Research Council, 20 Park Crescent, London W1V 4AL, UK}

John Treherne reviewed the book upon its publication in the United States (by Doubleday). In Britain, it is published today by Macdonald.

\section{How 'scientific' is whaling?}

SIR-As F. Nagasaki rightly points out (Nature 344, 189; 1990), "scientific" whaling can easily develop into an emotive issue where scientific considerations are secondary. However, the arguments advanced in support too readily assume the need to kill whales in order to study them. The very same issue of Nature describes non-lethal sampling of whale DNA $(344,238 ; 1990)$. Assuming adequate analysis of previously obtained material (for example the 600 southern minke in the Japanese survey 1987-89), it should be practicable to use genetic fingerprinting techniques to perform capture-recapture analysis. Reasonable estimates of total stock size and sexual composition will then be obtained. Assessing the age and maturity of individuals is more problematic. Crude estimates might be possible from observable physical characteristics such as length, relative size and so on of various features and sonar reflections. Over a number of seasons, estimates of abundance and sexual composition will give an indication of whether stocks are increasing or decreasing. Although this will take a period of years, it is prudent to consider carefully the case for whaling of selected species. The suggestion of resumption of commercial whaling within a year does seem indecent haste.

A discussion on the need (or otherwise) to determine age-specific natural mortalities would have been useful to help assess the case for 'scientific' whaling. If the research is to be seen as truly altruistic and not as a means of attempting to justify a return to commercial-scale whaling as soon as possible, it would have been better to commission research from another source, that some critics could not claim was tainted.

\section{Sapphire Street,} Cardiff CF2 1PZ, UK

ChRIS LLOYd MILLS

SIR-I was glad to see the case for scientific whaling clearly and explicitly presented by F. Nagasaki. He correctly says "many of those who oppose Japan's whaling operations do so for emotional reasons". But so what? May we not have and express emotions even if they are "without scientific bases"? Many of us who eat beef and mutton (thereby condoning the killing of cows and sheep) would nevertheless feel uncomfortable shooting foxes or killing and eating the flesh of dogs, horses or monkeys. I like whales, and so - if only for emotional reasons - I would feel happier if all whaling ceased.

RALPH A. LEWIN

Scripps Institution of Oceanography, University of California, San Diego, La Jolla, California 92093, USA

\section{Star wars}

SIR-The small laser-energized icerockets described by $\mathrm{G}$. Christopher Anderson (Nature 344, 91; 1990) represent just one of a number of proposed new ways of reducing space-launch costs. US Sandia National Laboratories researchers recently proposed 'coil guns'. Electromagnetic mass drivers were also advocated earlier by G. K. O'Neill for launching material (more cheaply) from the Moon or an asteroid.

By exploiting 'Star Wars' globalpositioning, sensor, guidance and steering technology, stretched-out packets of such extraterrestrial material, accelerated by gravity towards Earth, could be made to home in on and impact 'pusher plates', for example on initially slow vehicles lifted by 'air-breathing' ramjets to points just above the atmosphere. By using shockabsorbers and multiple impacts (as in 'Orion'-Project nuclear-bomb propulsion), power generation and moderate non-damaging acceleration of even fragile vehicles into orbit should then be possible.

For inter-orbital travel, elastic impacts could perhaps be achieved by utilizing rotating-cable impact material, one end of which would link up with a vehicle at zero relative velocity and swing it through a semi-circle to a higher or lower velocity. Two-way travel with virtually no net energy expenditure may then become feasible.

LOUISA. P. BALAZS

Department of Physics,

Purdue University,

West Lafayette, Indiana 47907, USA 